\title{
SOME COMPUTATIONAL RESULTS FOR FUNCTIONS BELONGING TO A FAMILY CONSISTING OF CAUCHY-EULER TYPE DIFFERENTIAL EQUATION
}

\author{
HÜSEYIN IRMAK
}

\begin{abstract}
In this study, a family concerning fractional calculus of $p$-valently analytic functions is first defined and several basic results for the related functions are next given. By making use of these results, several computational results for functions belonging to the family consisting of the (non-homogenous) Cauchy Euler type differential equation are then derived.
\end{abstract}

Mathematics subject classification (2010): 30C50, 30E20, 30C45, 26A33, 30A10.

Keywords and phrases: Unit disk, analytic function, $p$-valent function, Cauchy-Euler differential equation, complex inequalities, fractional calculus, distortion inequalities, coefficient bounds.

\section{REFERENCES}

[1] O. Altintas, O. OzKan, H. M. SRivastava, Neighborhoods of a certain family of multivalent functions with negative coefficients, Comput. Math. Appl., 47(10-11), 1667-1672, 2004.

[2] R. S. Barbosa, J. A. T. Machado, I. M. Ferreira, PID controller tuning using fractional calculus concepts, Frac. Cal. Appl. Anal., 7(2), 119-134, 2004.

[3] M.-P. Chen, H. Irmak, H. M. SRivastava, Some families of multivalently anlytic functions with negative coefficients, J. Math. Anal. Appl., 214(2), 674-690, 1997.

[4] M.-P. Chen, H. IRMAK, H. M. SRIVASTAVA, A certain subclass of analytic functions involving operators of fractional calculus, Comput. Math. Appl., 35(5), 83-91, 1998.

[5] P. L. DuREn, Univalent Functions, Grundlehren der Mathematischen Wissenschaften 259, SpringerVerlag, New York, Berlin, Heidelberg, and Tokyo, 1983.

[6] J. DZIOK, Classes of functions defined by certain differential-integral operators, J. Comput. Appl. Math., 105(1-2), 245-255, 1999.

[7] Z. E. A. Fellah, C. Depollier, Application of fractional calculus to the sound waves propagation in rigid porous materials: Validation via ultrasonic measurement, Acta Acustica, 88, 34-39, 2002.

[8] A. W. Goodmman, Univalent Functions, Vols. I and II, Polygonal Publishing House, Washington, New Jersey, 1983.

[9] H. IRMAK, S. B. Joshi, R. K. RaINA, On certain novel subclasses of analytic and univalent functions, Kyungpook Math. J., 46(4), 543-552, 2006.

[10] H. IRMAK, N. TUNES KI, Fractional calculus operator and certain applications in geometric function theory, Sarajevo J. Math., 6(1)(18), 51-57, 2010.

[11] H. IRMAK, R. K. RAINA, Some applications of generalized fractional calculus operators to a novel class of analytic functions with negative coefficients, Taiwanese J. Math., 8(3), 443-452, 2004.

[12] H. Irmak, Ö. F. Çetin, Some theorems involving inequalities on p-valent functions, Turkish J. Math., 23(3), 453-459, 1999.

[13] V. Kulish, L. Jose, LageApplication of Fractional Calculus to Fluid Mechanics, J. Fluids Eng., 124(3), 803-806, 2002.

[14] R. Magin, Fractional Calculus in Bioengineering, Part 1, Crit Rev Biomed Eng., 32(1), 1-104, 2004.

[15] R. L. Magin, Modeling the Cardiac Tissue Electrode Interface Using Fractional Calculus, Journal of Vibration and Control, 14(9-10), 1431-1442, 2008. 
[16] T. MARgULIES, Wave propagation in viscoelastic horns using a fractional calculus rheology model, Acoustical Society of America Journal, 114(4), 2442-2442, 2003.

[17] B. Mathieu, P. Melchior, A. Oustaloup, Ch. Ceyral, Fractional differentiation for edge detection, Fractional Signal Processing and Applications, 83(11), 2285-2480, 2003.

[18] S. OWA, On the distortion theorems. I, Kyungpook Math. J., 18(1), 53-59, 1978.

[19] S. OWA, H. M. SRIVASTAVA, Univalent and starlike generalized hypergeometric functions, Canad. J. Math., 39(5), 1057-1077, 1987.

[20] N. SebaA, Z. E. A. Fellah, W. Lauriks, C. Depolleier, Application of fractional calculus to ultrasonic wave propagation in human cancellous bone, Signal Processing Archive, 86(10), 26682677, 2006.

[21] E. SoczKIEwICZ, Application of fractional calculus in the theory of viscoelasticity, Molecular and Quantum Acoustics, 23, 397-404, 2002.

[22] H. M. SRivastava, S. Owa, Current Topics in Analytic Function Theory, World Scientific Publishing Company, Singapore, New Jersey, London, and Hong Kong, 1992. 